WELCOME NOTE

(cc) BY 4.0

\title{
UNITED NATIONS (UN) TEAM IN THE RUSSIAN FEDERATION
}

\author{
Vladimir V. Kuznetsov \\ United Nations Information Centre in Moscow \\ 9, Leontievsky Pereulok, Moscow, Russia, 125009
}

For citation

Kuznetsov, V. V. (2021). United Nations (UN) Team in the Russian Federation. Digital Law Journal, 2(2), 8-9. https://doi.org/10.38044/2686-9136-2021-2-2-8-9

On behalf of the team of the UN entities working in Russia, we welcome the international scientific and practical journal Digital Law Journal! The relevance of the topics covered on the pages of the journal is clear; the journal sets out not only to popularize international efforts to implement the UN 2030 Agenda for Sustainable Development, but also to show these themes in a practical plane, particularly regarding the legal regulation of the digital technology sphere.

As UN Secretary-General António Guterres rightly noted, "we all, figuratively speaking, sail on the same sea, but some at this moment are resting on their super-yachts, while others desperately cling to the wreckage passing by". The existing problems of equality, social justice, and the opportunity to equally benefit from the technological revolution (the so-called digital divide) are all critical issues; the rights people have to a more prosperous and secure future directly depend on solving these issues.

The team of the UN entities in Russia expresses its readiness for the closest cooperation with the editors of the Digital Law Journal in the name of more broadly informing the audience about important, complex, but interesting research related to international cooperation in the field of digitalization.

The special significance of this topic was emphasized during the speech of the UN Secretary General at the MGIMO University, which became an important event during A. Guterres' visit to Moscow on May 12-14, 2021.

We wish the journal and its readers new interesting research and discussions in the name of realizing the common goals of building a more prosperous and secure digital future for all!

Moscow, June 2021

Information about the author:

Vladimir V. Kuznetsov - Director of the United Nations Information Centre in Moscow, Moscow, Russia. unic.moscow@unic.org 